\title{
A PALAEOSTACHYA FROM THE PENNSYLVANIAN OF KANSAS ${ }^{1}$
}

\section{Theodore Delevoryas}

UNTIL RECENTLY, most of our knowledge of the anatomy of the calamitean cone genus Palaeostachya Weiss (1876) was derived from studies of $P$. vera Seward (1898). Originally described by William. son $(1871,1888)$ as Calamites pedunculatus, this species was later described in more detail by Hickling (1907). The last-named author observed the peculiar course of the sporangiophore traces which ascended almost to the middle of the internode, then bent abruptly backward and entered the axillary sporangiophore. Several subsequent authors (e.g., Janssen, 1939, fig. 73a; Arnold, 1947, pp. 149-150) have dealt with this particular feature as a generic character. Iis his original account of Palaeostachya, however, Weiss (1876) made no reference to the course of the trace, and merely stated that Palaeostachya differed from Calamostachys and other types of calamitean cones by having sporangiophores in an axillary position. This feature has been widely used by authors in assigning compressions lacking anatomical details to Palaeostachya (Weiss, 1876, 1884; Kidston, 1914, pl. Ix, fig. 3; pl. xI, fig. 1; Crookall, 1929, pl. xxv, fig. i, j; Janssen, 1939, fig. 75; Arnold, 1949, pl. Xvi, fig. 2,3 ; etc.).

In all species of Palaeostachya where it is possible to observe the relationship of sporangiophores to bracts, there is no instance where a bract actually subtends a sporangiophore. Palaeostachya vera comes the closest to showing such a condition, but according to Hickling (1907) the bracts are approximately equal in number to the sporangiophores, but sometimes are more abundant. The concept of "axillary" as used by Weiss, Scott (1920, p. 54), Hirmer (1927, p. 405), Darrah (1939, p. 115), Arnold (1947, p. 149), and undoubtedly others, simply referred to the fact that the sporangiophores arose from the cone axis at the base of the cup formed by the whorl of sterile bracts. Thus, in referring to the axillary insertion of sporangiophores in Palaeoslachya, the author is merely using a convenient term to describe the general position of sporangiophores on the cone axis.

The well-preserved cone described by Baxter

${ }^{1}$ Received for publication December 9, 1954.

Much of this investigation was carried on while the author was a Rockefeller Fellow in the Natural Sciences of the Naiconal Research Council. He is indebted to Professor W. N. Stewart for loan of the material and for assistance during the early stages of this project. To Professor C. A. Arnold, for his critical reading of the manuscript and for many helpful suggestions, and to Dr. Jeanne Morgan for her assistance, the author is grateful. Thanks are extended to Professor R. W. Baxter for loan of his manuscript prior to its publication.
(1955) as Palaeostachya andrewsii reveals many of the features Hickling saw in $P$. vera, the species it most closely resembles. The identity of the course of the sporangiophore traces in these two species suggests that it might be one of the basic anatomical features of the genus.

Several cones recently found in a coal ball from a strip mine of the Pittsburgh and Midway Coal Company four miles south of West Mineral, Kansas, show structural features heretofore unknown in Palaeostachya, although in other respects these cones conform to the genus. The coal ball was heavily pyritized so that many of the structures of the cone were obscured. Fortunately, however, small parts of the seven cones were well enough preserved to allow a reconstruction of an entire cone. Furthermore, four of the cones were attached to one axis so a comparison of the attachment of cones of this species with that in certain compression forms (e.g., P. pedunculata Weiss, 1884) can be made.

General Description.-Including the pedunculate base (which is a little more than one $\mathrm{cm}$. long) a single cone is almost $5 \mathrm{~cm}$. long and about 8.5 mm. in width. The four cones attached to the parent axis are arranged in two pairs, one about $3 \mathrm{~cm}$. from the other, and each strobilus is in the axil of a bract. The axis, its bracts, and the cone peduncles are considerably pyritized and show nothing but the general shape and arrangement. As a result no satisfactory photograph could be obtained, but the diagram in fig. 1 serves to show cone arrangement. In at least one of the cones there are 10 nodes, at each of which a set of radiating sporangiophores is subtended by a whorl of bracts. In two of the cones sectioned transversely the number of sporangiophores in a single whorl is 10 , and this number appears to be the same at all levels of the same cone (fig. 5, 10). With four sporangia attached to the end of each sporangiophore, and directed toward the cone axis, 40 is the usual number for a single whorl. Each of the subtending bracts is fused to those adjacent only at its base, and is free from that point to its tip. Figures 4 and 6 show the fused bract bases in tangential section. A total of 20 bracts, or twice the number of sporangiophores, constitutes each subtending whorl. The ratio of two bracts per sporangiophore agrees with that in $P$. andrewsii in which 24 bracts subtend 12 sporangiophores. The arrangement of sporangiophores of adjacent whorls in a vertical alignment is confirmed both by tangential sections and by successive cross-sections. It is probable that the bracts were also superposed. 


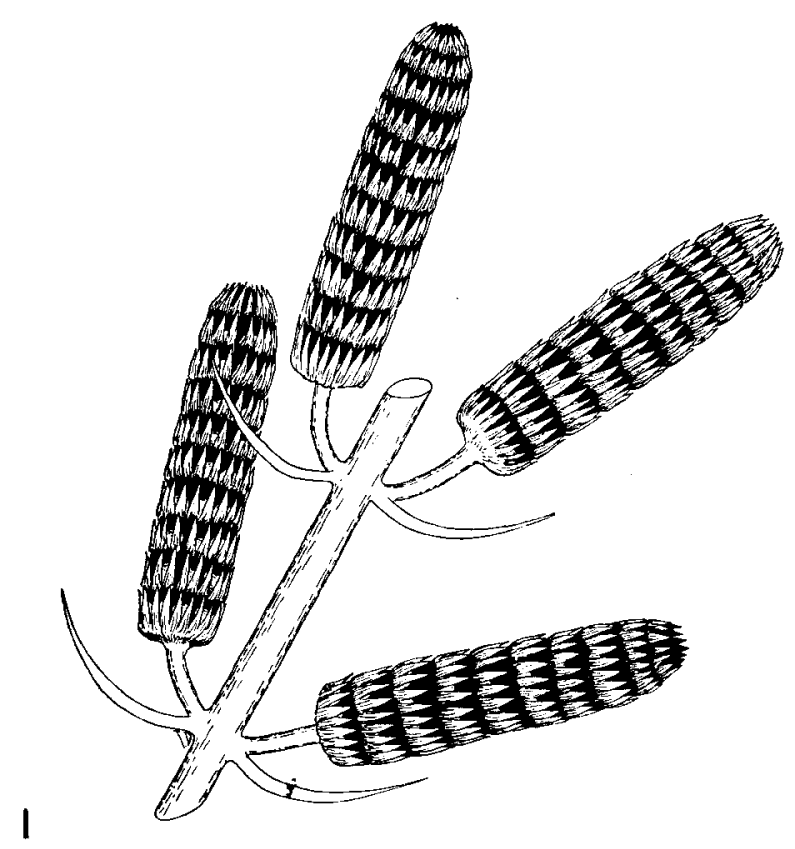

2

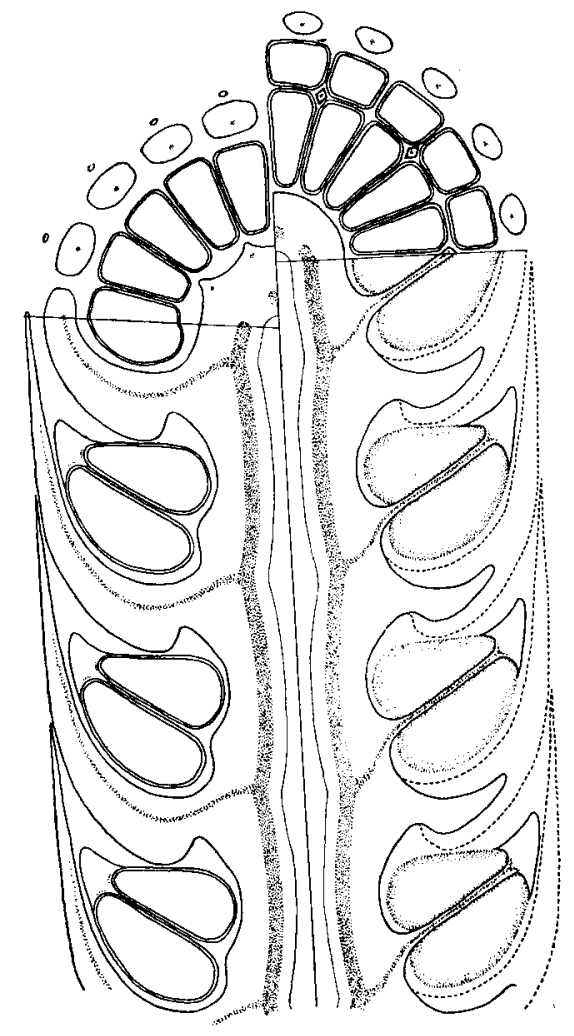

Fig, 1-2.-Fig. 1. Diagrammatic reconstruction of cones of Palaeostachya decacnema showing their attachment to the parent axis. Based on a series of peels from C. B. $2984 \mathrm{c}$ bottom and d top.-Fig. 2. Idealized transverse and longitudinal sections of a portion of a cone of $P$. decacnema. The longitudinal section at the right of the diagram represents a section through the sporangiophores, but not the sporangia, while the left side is a section through the sporangia, but not the sporangiophores. Axis, bract, and sporangiophore vascular systems are stippled.

Quite likely the bracts were displaced somewhat during fossilization and may not always appear superposed, but the vascular strands supplying the bracts originate in corresponding positions at each of the nodes.

Cone axis.-Below the lowest whorls of bracts the cone axis is continuous with a peduncle a little more than $1 \mathrm{~cm}$. in length and about $2 \mathrm{~mm}$. in diameter. At an internode the cone axis is $2.5 \mathrm{~mm}$. in width but it appears to be considerably wider at the nodes because of the congestion of bract and sporangiophore bases. The pith of the cone axis is hollow for its entire length (there are no nodal diaphragms), with the cavity extending through the peduncle below.

Sporangiophores.-From their point of attachment to their distal extremities, the sporangiophores average $2.7 \mathrm{~mm}$. in length, with an average diameter of $0.25 \mathrm{~mm}$. The configuration in cross-section is square or rhombic (fig. 6). The expanded tip of the sporangiophores is neither strictly peltate, as in $P$. andrewsii (Baxter, 1955), nor cruciate, as Lacey (1943) reported for certain Calamostachys sporangiophores. A longitudinal section shows the extremity seemingly expanded into a peaked structure (fig. 7). Actually, however, it does not end in a point but rather in a tangentially-elongated fleshy ridge (fig. 8). The outer faces of the lower two sporangia are covered by a downward projection of the sporangiophore apex on either side of the narrower middle portion (fig. 8). Although the sporangiophores are inserted at a level slightly above the bracts, they are much closer to the whorl of bracts below than to the whorl above. Hickling (1907) observed that the sporangiophores of $P$. vera did not arise at the same level as the bracts and wrote: "In an external view these organs [sporangiophores] must have appeared to be practically in the axils of the bracts, though as will be realized from an examination of the oblique nodal section, Fig. 7, they did not become completely free for a short distance above the insertion of the bract." As in all previously described petrified species of Palaeostachya, the sporangiophores of the recently discovered cones are not attached to the cone axis at right angles as in Calamostachys, but incline upward from their point of attachment (which is only slightly above the level of the bracts) to the distal end (fig. 2, 7).

Bracts.-In general, preservation of the bracts is 
rather poor, but in those places where they are present, there are 20 in each whorl, or twice as many as the sporangiophores. Adjacent bracts are fused at their bases, but most of their length is free. Near the base of each bract is a "heel" which, unlike those of other sphenopsid cones (e.g., $P$. vera, certain species of Calamostachys, Cheirostrobus), does not project over the outside of the sporangia in the whorl below, but is close to the proximal portion of the bract (fig. 3,4 ). The bracts may extend half-way up the second internode above the level of their origin, although usually they are not quite that high. As a result, there are never bracts of more than two nodes visible in any crosssection of the cone.

Sporangia.-Sporangia are attached to the sporangiophore only at the tip, and are directed toward the cone axis. They average $2 \mathrm{~mm}$. in length and $1 \times 0.8 \mathrm{~mm}$. in maximum width. Each sporangium is somewhat pear-shaped in longitudinal section (fig. 3, 11), although a cross-section (as shown in a tangential section of the cone) reveals a tetragonal outline (fig. 6). This configuration is probably. the result of the crowding of so many sporangia in a whorl. The sporangium wall consists of a single layer of cells measuring $160 \times 26 \mu$ and which are elongated in a direction parallel with the long axis of the sporangium. As in most sphenopsid sporangia, the cells of the wall layer possess a number of inwardly projecting buttresses, which are rather evenly spaced (fig. 14). An anticlinal section of the sporangium often shows a wall that appears to be composed of small isodiametric cells (fig. 13). That is probably the reason Baxter (1955) described the sporangium wall in $P$. andrewsii as consisting of "closely packed" cells. A peel of $P$. andrewsii loaned to the author by Baxter showed some periclinal sections of sporangia and the buttressed cells were evident.

Spores contained within the sporangia are smooth-walled and spherical, averaging $45-50 \mu$ in diameter. The spore wall is about $2 \mu$ thick and includes a thin perispore which frequently is separated from the rest of the spore coat. Each spore has a triradiate scar with the three rays extending from one-half to two-thirds the distance to the margin of the spore. In each of the three angles of the scar is a darker area representing the point of contact of one of the three other spores in the tetrad (fig. 15). On some of the spores these contact areas are not visible, probably because of the separation of the perispore. These spores are assignable to the genus Calamospora (Schopf et al., 1944). Spores of the new cones are all the same size, suggesting either that this species of Palaeostachya is homosporous, or, if heterosporous, the microspores were borne in cones separate from those bearing megaspores.
Vascular system.-A set of "double bundles,"2 like those commonly found in calamitean cones, runs the length of the cone axis. Five is the typical number in these cones. Each double bundle has two protoxylem canals accompanied by centrifugal metaxylem (fig. 9, 10). The cells of the pith tissue which persists in the axis are comparatively thickwalled, and resemble the tracheids in cross-section, but differ in their larger diameter. In places it is possible to discern radiating rows of secondary tracheids external to the metaxylem. The poor preservation of parts of the cones obscured the structure of the vascular supply of the cone axis in places, so it could not be determined whether secondary development is constant in all parts of the cones.

Most of the sporangiophore traces are preserved as dark brown strands with cellular details obscured. In parts of these traces, however, secondary thickenings can be observed on some of the cell walls (fig. 12), showing that those cells represent the vascular elements of the sporangiophores. One sporangiphore trace arises from each lobe of the double bundle opposite each protoxylem canal (fig. 10). The sporangiophore trace follows an almost direct course into the sporangiophore (fig. 11), a feature which is quite different from the situation in $P$. vera and $P$. andrewsii, where the trace takes an almost vertical course after its separation from the vascular supply of the axis, then bends back down, and finally follows an inclined path into the sporangiophore.

At the expanded apex of the sporangiophore, the trace divides twice to form four strands, each of which supplies one sporangium (fig. 8).

Bract traces arise only slightly below the sporangiophore traces (fig. 2). Four originate from each double bundle, one from metaxylem flanking either side of each protoxylem canal. Only one trace supplies each bract. Beyond their point of origin, these traces bend downward slightly, then arch upward within the bract bases. The extension of the trace into a bract could not be observed.

The relation between the sporangiophores and their subtending bracts should be explained at this point. The number of bracts is double that of the sporangiophores, and each sporangiophore is subtended by a bract pair, not a single bract. The sporangiophore trace arises slightly above and between the members of the pair. Although there are 20 bracts in a single whorl, this number may be considered to be composed of 10 pairs of bracts, and the traces of both members of each pair arise from the same lobe of the double bundle as does the trace of the sporangiophore above them. A similar

\footnotetext{
2 The double bundle in many calamitean cones consists of two laterally fused strands, and should not be confused with leaf traces of many gymnosperms, also referred to as double bundles, but which consist of a pair of separate bundles.
} 


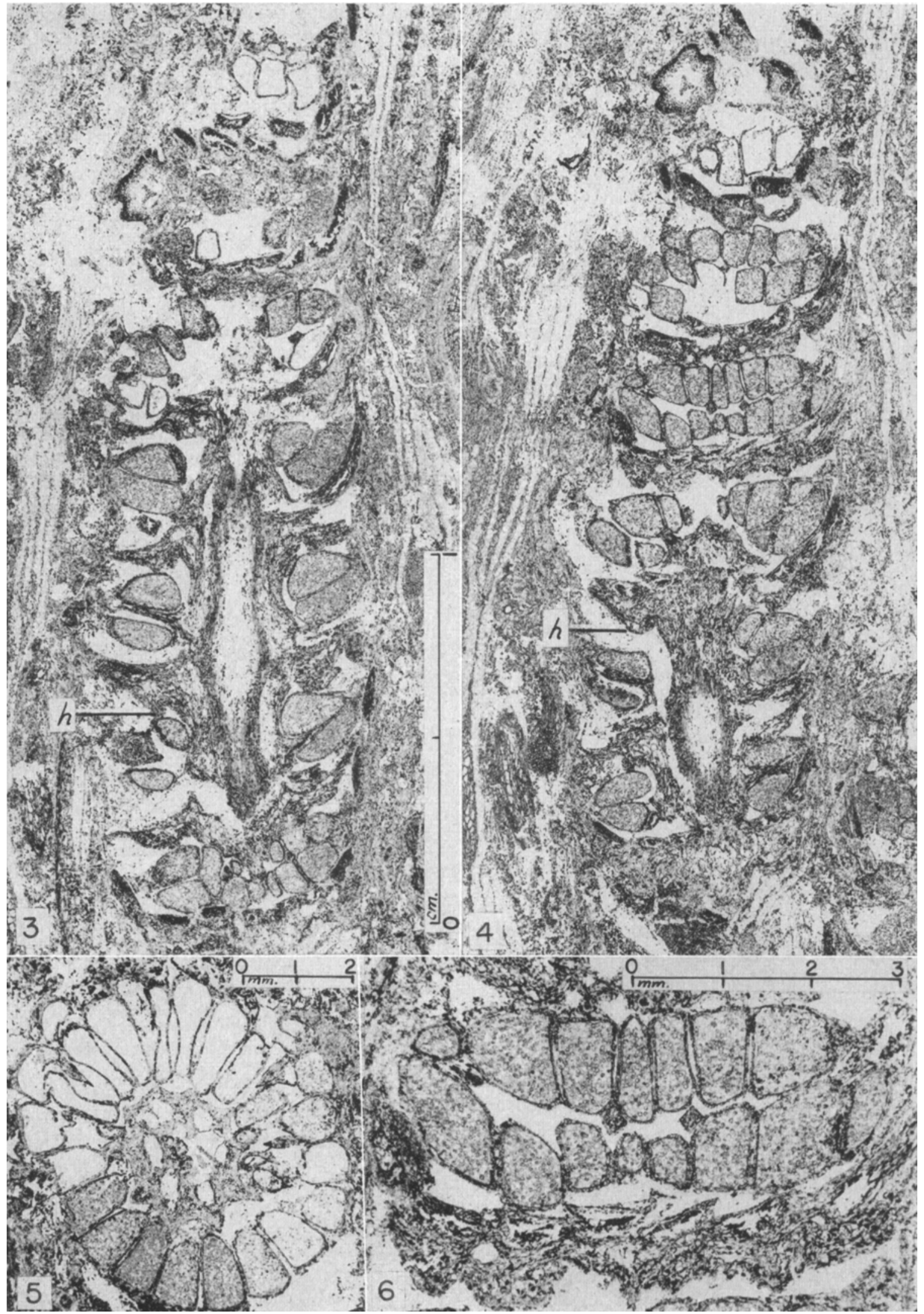


relationship between sporangiophores and bracts exists in $P$. andrewsii.

Palaeostachya decacnema $\mathrm{sp}$. nov. ${ }^{3}$-Diagnosis-Pedunculate cones almost $4 \mathrm{~cm}$. in length, $0.85 \mathrm{~cm}$. in width, borne on peduncles $1 \mathrm{~cm}$. long; cones borne axillary on parent axis. Cones with about 10 whorls of sporangiophores and bracts, with 10 sporangiophores and 20 bracts at each node. Vascular supply to the sporangiophores and bracts arising from five "double bundles" which run the length of the cone axis; traces to sporangiophores arising at a level just above the point of origin of bract traces and following an oblique course into the sporangiophore. Sporangia $2 \mathrm{~mm}$. long, $1 \times 0.8 \mathrm{~mm}$. in width; apex of sporangiophore expanded into a tangentially elongated fleshy ridge; spores (microspores?) of the Calamospora type, smooth walled, $45-50 \mu$ in diameter, spore wall $2 \mu$ thick, with a triradiate scar with rays extending from one-half to two-thirds the distance to the margin; contact areas present in angles of triradiate scar.

Stratigraphic occurrence--Fleming coal, Cherokee shale, Des Moines series of Kansas.

Age.-Middle Pennsylvanian.

Syntypes.- Specimens in Coal Ball 2984 in the Paleobotanical Collections, Department of Botany, University of Illinois; other slides are in the Museum of Paleontology, University of Michigan.

Discussion.- It is not difficult to distinguish $P$. decacnema from any of the other previously described petrified forms of Palaeostachya since the new species has several characteristic features. Palaeostachya decacnema is smaller than $P$. vera (Hickling, 1907), P. schimperiana (Selling, 1944), $P$. multifolia (Anderson, 1954), and $P$. andrewsii (Baxter, 1955), and is typified by 10 sporangiophores per node. There is no reason to believe that all cones of this species have the same number of sporangiophores at each node, and a slight fluctuation, above or below 10 might be expected. Nevertheless the number is still considerably smaller than in the four species named above. 'The presence of twice as many bracts as sporangiophores at a node of $P$. decacnema is a further means of separating it from $P$. vera and $P$. schimperiana. In $P$. vera there seems to be no definite numerical relationship between bracts and sporangiophores, since, according to Hickling, bracts may have been equal in number to the sporangiophores, or may have exceeded that number. In $P$. schimperiana bracts are

3 From the Greek deka $=$ ten + kneme $=$ spoke of a wheel; alluding to the presence of 10 sporangiophores at each node. equal in number to sporangiophores at a node and alternate with them. Although $P$. gracilis ( $V$ olkmannia gracilis of Renault, 1882, pp. 115-118, pl. 18, fig. 3, 4) also has 10 sporangiophores and 20 bracts at each node, its bracts are free all the way to their bases, and in a cross-section, bracts from several nodes are visible. The peculiar fleshy ridged sporangiophore apex in $P$. decacnema is another feature which had not been reported in the forms described earlier. The most interesting point in the anatomy of $P$. decacnema is the path followed by the sporangiophore trace.

Although the insertion of the sporangiophores of $P$. decacnema at a slight distance above the bract whorl might suggest that they are not really axillary, they are definitely closer to the whorl of bracts below them than to the whorl above. In almost all instances (except for a few places where the sporangiophores have been mechanically displaced) the sporangiophores are inclined slightly upward, and are not perpendicular to the cone axis as in Calamo. stachys. Hickling (1907) wrote that in P. vera the insertion of the sporangiophores is a little above the level of bract insertion, and Lady Isabel Browne (1927, p. 307) mentioned that in Palaeostachya the sporangiophores may stand in the axils of, or $a$ little above, the bracts.

The importance of certain facts concerning the anatomy of Palaeostachya and Calamostachys must be weighed before we can settle the problem of determining relationships among calamitean fructifications. Two specimens of $P$. multifolia (identified by Dr. Anderson ) in the Paleobotanical Collections, Department of Botany, University of Illinois, have sporangiophores which are not as close to the level of bract insertion as Anderson's (1954) text-fig. 1 would seem to indicate. He placed these, and his specimens, in the genus Palaeostachya because nodal characters were absent in the cone axis between bract nodes (e.g., protoxylem canals in the cone axis disappear at bract nodes but are continuous opposite the sporangiophores). He considered this feature to be of more significance in identifying his specimens than the fact that the sporangiophores are attached at a level rather high up on the "internode." In a relatively unknown paper, Hickling (1910) reported on an investigation of the vascular anatomy of Calamostachys binneyana and found that there, too, nodal characteristics are absent in the pith at the level of attachment of sporangiophores. In the bract nodes, the pith cells are considerably shorter than those in the "internode." In addition, he maintained that the traces to the sporangiophores arise at the bract

Fig. 3-6. Palaeostachya decacnema.-Fig. 3. Slightly oblique longitudinal section of a cone. The middle lower portion is nearly radial. $h$-heel. C. B. 2984 c(1) bottom 27.-Fig. 4. Slightly oblique longitudinal section of the same cone showing features apparent in tangential section. $h$-heel. C. B. $2984 \mathrm{c}(1)$ bottom 1.-Fig. 5 . Cross-section of a cone. Note the 10-lobed nature of the cone axis (lobes represent sporangiophore bases). Details of the cone axis in this section are obscured by pyrite. C. B. $2984 \mathrm{~d}(2)$ edge 9.-Fig. 6. Enlargement of part of the section in fig. 4 . The fused bract bases are evident below the sporangia. C. B. $2984 \mathrm{c}(1)$ bottom 1. 


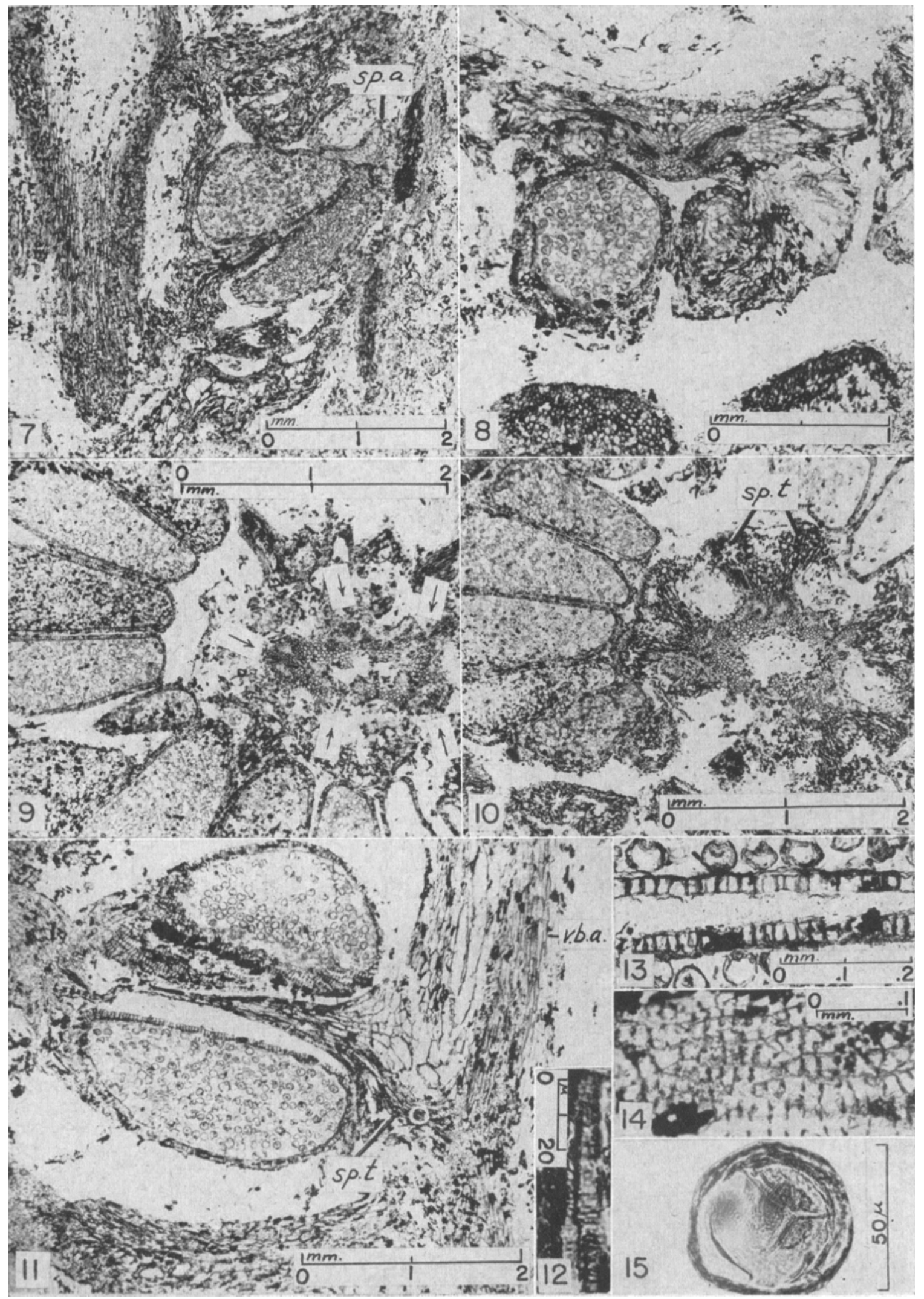


node, follow the stele upward, and bend outward approximately at right angles at the position of sporangiophore attachment. If these observations hold true in all species of Calamostachys (Hickling confined himself to only one species) the difference between Palaeostachya and Calamostachys is not very great. If the sporangiophores in $P$. decacnema and $P$. multifolia had been attached only a little higher on the internode their generic identification would be entirely subjective since they would closely resemble the Calamostachys type of cone.

In view of the various sporangiophore positions and configurations of the sporangiophore traces among genera of calamitean cones, it may be necessary to define our concepts of the term "axillary" as applied to sporangiophore position in Palaeostachya. There is a considerable range of sporangial position in calamitean fructifications, from one type which appears to be axillary (Palaeostachya), through one with sporangiophores borne midway between bract whorls (Calamostachys), to types with sporangia borne immediately below the bract whorls (Cingularia). All these seemingly diversified genera may be regarded as possessing homologous structures, and may simply represent types with sporangia attached at different places along the internode. Cingularia represents a form with sporangiophores attached to the highest possible level on the internode, and Palaeostachya has sporangiophores arising from the lowest level possible. Therefore the "axillary" feature of Palaeostachya suggests no structural relationship between bract and sporangiophore (as in seed plants, for example, where the leaf and subtended branch have a very close structural association) but is merely a characteristic derived by phyletic "migration" of sporangiophores. It is not unlikely that a true axillary type was the precursor of calamitean cones, since sporangiophore traces (even in Calamostachys binneyana) arise from the bract node. The configurations present in the known types of calamitean cones are thus only modifications of the earlier type, with some (e.g., Palaeostachya vera and $P$. andrewsii) mimicking the original axillary condition. Palaeostachya decacnema may be interpreted as showing a primitive condition since traces enter the sporangiophore in an almost direct course from their point of origin. An alternative interpretation of the situation in $P$. decacnema is to consider it a condition derived from such types as $P$. vera and $P$. andrewsii. The axillary condition in those two species is said to have been derived from the Calamostachys condition by a "phyletic slide" of the sporangiophores from a position half-way between bract nodes, to one just above the lower whorl of bracts (Hickling, 1907; Anderson, 1954; Baxter, 1955). In P. vera and $P$. andrewsii the course of the sporangiophore traces testifies to such an origin of the axillary fertile whorls in those species. Such a phyletic slide carried to completion would ultimately involve the vascular system, and the outcome would be a cone such as $P$. decacnema where the course of the trace into the sporangiophore is a direct one.

The source of sporangiophore traces in Calamostachys and Palaeostachya from the bract nodes adds support to Lignier's (1903) hypothesis that a cone with axillary sporangia was ancestral to those two genera.

In his paper, Baxter (1955) emphasized that the apex of the sporangiophore in $P$. andrewsii was peltate, and definitely not cruciate as was shown for Calamostachys binneyana by Lacey (1943). In $P$. decacnema it appears to be neither cruciate, nor strictly peltate, but is an elongated fleshy ridge. The differences among the expanded sporangiophore tips in calamitean fructifications should, however, be regarded as a minor one, since all can be derived from a single basic form. The most simple type would be the cruciate one, with a progressive amount of webbing being responsible for those that are peltate or nearly so. Considerably more "flattening" in the vertical direction occurred in $P$. decacnema than in the other types.

One of the problems which remains in the study of calamitean fructifications is to determine which of the arborescent sphenopsids were heterosporous, and which, if any, were homosporous. Although Calamostachys casheana and Palaeostachya multifolia are the only known calamitean fructifications with both microspores and megaspores in the same strobilus, the possibility must not be overlooked that among the other species, certain cones possessed only microspores, while others were megasporous. Baxter (1955) admitted that possibility in his de-

Fig. 7-15. Palaeostachya decacnema.-Fig. 7. Longitudinal section of a portion of a cone showing attachment of a sporangiophore and the expanded sporangiophore apex. sp. ap.-apex of sporangiophore. C. B. 2984 c(1) bottom 27.Fig. 8. Tangential section of a portion of a strobilus through the apex of a sporangiophore. The dividing vascular strand is visible near the middle of the narrow part of the sporangiophore apex. C. B. $2984 \mathrm{~d}$ top 13.-Fig. 9. Transverse section of a cone showing the position of the five "double bundles" (indicated by arrows). Protoxylem canals are clearly visible in the bundle at the left. C. B. 2984 c (1) (a) edge 24.-Fig. 10. Transverse section at a higher level. Two sporangiophore traces can be seen arising from each bundle (the two at the lower left of the photograph are not preserved). sp. $t .-$ sporangiophore traces. C. B. $2984 \mathrm{c}$ (1) (a) edge 44,-Fig. 11. Radial section showing the path followed by the sporangiophore trace from its point of origin in the vascular supply of the cone axis. $s p$. $t$. - sporangiophore trace; $v$. b. $a .-$ vascular bundle in cone axis. C. B. 2984 c(1) bottom 28.-Fig. 12. Part of a tracheid in the sporangiophore trace in fig. 11. The white circle in fig. 11 indicates the location of the tracheid in fig. 12. C. B. 2984 c(1) bottom 28.--Fig. 13. Anticlinal longitudinal section through two adjacent sporangia showing the appearance presented by the buttresses in such a section. C. B. $2984 \mathrm{c}(1)$ bottom 31.-Fig. 14. Periclinal section of a sporangium showing the true nature of the buttressed cells. C. B. $2984 \mathrm{c}(1)$ bottom 26,--Fig. 15. Spore of $P$. decacnema. C. B. $2984 \mathrm{e}(1)$ bottom 33. 
scription of $P$. andrewsii. This idea is further subsiantiated by Anderson's (1954, pp. 411-412) report of a cone (Palaeostachya sp.) which appears to be identical with Baxter's $P$. andrewsii, but differs in the presence of smaller spores. The size of the spores in the type specimen of $P$. andrewsii (270$320 \mu$ ) would easily suggest that they are megaspores. All the cones of $\boldsymbol{P}$. decacnema investigated had spores of one size, so nothing further was contributed by this study toward the clarification of the problem.

\section{SUMMARY}

Palaeostachya decacnema is described as a new species of calamitean cone, originating from the Pennsylvanian of Kansas. At each node a whorl of
10 sporangiophores is subtended by a whorl of 20 bracts. Unlike $P$. vera and $P$. andrewsii, the sporangiophore trace follows an almost direct course into the sporangiophore. Attention is called to Hickling's (1910) paper describing the anatomy of Calamostachy binneyana in which nodal characters are absent at the sporangial level and sporangiophore traces are said to originate at the bract node. These observations seem to indicate that the difference between Calamostachys and Palaeostachya is not great, and suggest that a cone with a truly axillary condition was the precursor of these two types of fructifications.

\section{Museum of Paleontology, University of Michigan, Ann Arbor, Michigan}

\section{LITERATURE CITED}

Andirson, B. R. 1954. A study of American petrified calamites. Ann. Missouri Bot. Gard. 41: 395-418.

ArNold, C. A. 1947. An introduction to paleobotany. MeGraw-Hill. New York.

_- 1949. Fossil flora of the Michigan coal basin. Univ. Michigan Contrib. Mus. Paleont. 7: 131-269.

Baxter, R. W. 1955. Palaeostachya andrewsii, a new species of calamitean cone from the American Carboniferous. Amer. Jour. Bot. 42: 342-351.

Browne, Isabel M. P. 1927. A new theory of the morphology of the calamarian cone. Ann. Bot. 41: 301-320.

Crookall, R. 1929. Coal Measure plants. Edward Ar. nold. London.

Darrah, W. C. 1939. Textbook of paleobotany. D. Appleton-Century. New York.

Hickling, G. 1907. The anatomy of Palaeostachya vera. Ann. Bot. 21 : 369-386.

- 1910. The anatomy of Calamostachys binneyana. Mem. Proc. Manchester Lit. Phil. Soc. 54 (17) : 1-16.

Hirmer, M. 1927. Handbuch der Paläobotanik. R. Oldenbourg. Munich and Berlin.

Janssen, R. E. 1939. Leaves and tems from fossil forests. Illinois State Mus. Pop. Sci. Ser. Vol. I. Springfield.

Kidston, R. 1914. On the fossil fora of the Staffordshire coal fields. Part III.-The fossil flora of the Westphalien series of the south Staffordshire coal field. Trans. Roy. Soc. Edinburgh 50: 73-190.
LAcky, W. S. 1943. The sporangiophore of Calamostachys. New Phytol, 42: 98-102.

Lignikr, O. 1903. Equisétales et Sphénophyllales. Leur origin filicinéenne commune. Bull. Soc. Linn. Normandie V. 7 : 93-137.

Renault, B. 1882. Cours de botanique fossile. Vol. 2. G. Masson. Paris.

Schopf, J. M., L. R. Wilson, and R. Bentall. 1944. An annotated synopsis of Paleozoic fossil spores and the definition of generic groups. Illinois State Geol. Survey Rept. Investig. 91: 1-73.

ScotT, D. H. 1920. Studies in fossil botany. Vol. I. A. \& C. Black. London.

SFward, A. C. 1898. Fossil plants. Vol. I. Cambridge Univ. Press. Cambridge.

WEIss, C. E. 1876. Steinkohlen-Calamarien, mit besonderer Berücksichtigung ihrer Fructificationen. Abhandl. Geol. Specialkarte Preuss. u. Thür. Staaten 2, no. 1.

—. I884. Ibid. 5, no. 2.

Will.iamson, W. C. 1871. On a new form of calamitean strobilus from the Lancashire Coal-measures. Mem. Lit. Phil. Soc. Manchester III, 4: 248-265.

. 1888. On the organization of the fossil plants of the Coal-measures. XIV. The true fructification of Calamites. Phil. Trans. Roy. Soc. London B. 179: 4757. 